\title{
EUROSON 2016 Leipzig, Germany
}

the abstract book and final programme are now available online: ultrasound2016.org 